\title{
Proctocaecum gairhei n. sp. (Digenea: Cryptogonimidae: Acanthostominae) from Gavialis gangeticus (Gmelin) in Nepal and a revised cladogram of Proctocaecum Baugh, 1957
}

\author{
Kerstin Junker $^{1}$, Daniel R. Brooks ${ }^{2}$ and Joop Boomker ${ }^{1}$ \\ (1) Department of Veterinary Tropical Diseases, University of Pretoria, Private Bag \\ X04, Onderstepoort, 0110, South Africa \\ (2) Department of Zoology, University of Toronto, Toronto, ON, Canada, M5S 3G5
}

Joop Boomker
Email: joop.boomker@up.ac.za

\begin{abstract}
Proctocaecum gairhei $\mathrm{n}$. sp. is described from the gharial Gavialis gangeticus (Gmelin) in Nepal. The new taxon can be distinguished from all other species of Proctocaecum Baugh, 1957 by the combination of the following morphological characters: a single row of 23 cephalic spines, lateral anal pores opening at uneven levels, a forebody accounting for $16 \%$ of the total body length (TBL), an oral to ventral sucker width ratio of 1:0.7, an oral sucker to pharynx width ratio of 1:0.6 and uterine loops that occupy 59-67\% of the TBL. While sharing some morphological characteristics with Acanthostomum slusarskii Kalyankar, 1977 from Crocodylus palustris (Lesson) in India, P. gairhei $\mathrm{n}$. sp. is distinguished from the latter by possessing the solid muscular gonotyl diagnostic for Proctocaecum, by the number of cephalic spines, position of the anal pores and egg size. The existing cladogram for Proctocaecum was expanded using the character information of $P$. gairhei n. sp. The host range of Proctocaecum is now known to include all three families of the order Crocodylia.
\end{abstract}

\section{Introduction}

The acanthostomine genus Proctocaecum Baugh, 1957, characterised by its gonotyl which is in the form of a solid muscular pad, currently comprises 10 species (Brooks, 2004). Two of these, P. coronarium (Cobbold, 1861) and P. macroclemidis (Tkach \& Snyder, 2003), have been recorded from North America, where $P$. coronarium parasitises Alligator mississippiensis (Daudin) and Crocodylus acutus (Cuvier). P. macroclemidis was collected in the Alligator snapping turtle Macroclemys temmincki (Troost) and is to date the only species of the genus known to utilize a non-crocodilian host. A single 
species, $P$. dorsale Catto \& Amato, 1993, has been described from Caiman yacare (Daudin) in South America. On the African continent, the Nile crocodile $C$. niloticus (Laurenti) harbours three species, $P$. gonotyl (Dollfus, 1950), P. productum (Odhner, 1902) and $P$. vicinum (Odhner, 1902). A further three species, $P$. atae (Tubangui \& Masiluñgan, 1936), P. crocodilii (Yamaguti, 1954) and P. elongatum (Tubangui \& Masiluñgan, 1936), have been recorded in C. porosus Schneider from the Indomalayan region, and P. nicolli Brooks, 1980 was collected from C. johnsoni Krefft in Australia (Yamaguti, 1958; Brooks, 1980; Catto \& Amato, 1993; Tkach \& Snyder, 2003).

This paper describes a new species of Proctocaecum, P. gairhei n. sp., from the gharial Gavialis gangeticus (Gmelin) in Nepal. This is the first record of a member of the cryptogonimid subfamily Acanthostominae from the crocodilian family Gavialidae, which have now been reported from all three families comprising the order Crocodylia.

\section{Materials and methods}

During January to April, 2007, digeneans were collected from 7-10 month-old gharial hatchlings which had died at the Gharial Breeding Centre (GBR) of the Chitwan National Park, Kasara, Chitwan, Nepal. This captive rearing and release programme had been initiated in 1978 in order to save the critically endangered gharial from extinction. The survival rates of hatchlings at the GBR remained low, however, and in 2006 an investigation on the possible causes of mortality was begun based on 137 dead hatchlings (Gairhe, 2007).

The gharial hatchlings had been housed in an artificial nursery pool, sub-divided into six $4 \times 2 \mathrm{~m}$ ponds, with a maximum depth of $50 \mathrm{~cm}$ and an included sand-filled basking area. The water for the nursery pool was taken directly from a nearby creek and changed daily. Up to almost three months of age, hatchlings were force fed small, fresh fish collected from the local Rapti River until they began to eat by themselves (Gairhe, 2007).

Shortly after death, the gharials were frozen and subsequently thawed for examination. Digeneans collected from the intestines during this post-mortem examination were fixed in $70 \%$ ethanol and submitted to the authors for identification.

The worms were cleared and mounted in Hoyer's medium and examined under a light microscope. Measurements are in micrometres unless otherwise stated; for twodimensional structures, length is given before breadth. Drawings were made with the aid of a drawing tube.

Type-specimens were deposited in the helminth collection of the Natural History Museum (BMNH), London, UK, and their accession numbers are as indicated in the description.

The revised cladogram of Proctocaecum is based on the 11 characters specified by Brooks (2004), which were as follows (TBL = total body length). Table 1 contains the data matrix. 
Table 1 Data matrix for 11 species of Proctocaecum and 11 comparative morphological characters

\begin{tabular}{|l|l|l|l|l|l|l|l|l|l|l|l|l|l|l|l|l|l|l|}
\hline Characters & $\mathbf{1}$ & $\mathbf{2}$ & $\mathbf{3}$ & $\mathbf{4}$ & $\mathbf{5}$ & $\mathbf{6}$ & $\mathbf{7}$ & $\mathbf{8}$ & $\mathbf{9}$ & $\mathbf{1 0}$ & $\mathbf{1 1}$ \\
\hline P. coronarium & 1 & 1 & 1 & 1 & 1 & 1 & 0 & 0 & 0 & 0 & 0 \\
\hline P. vicinum & 1 & 1 & 1 & 0 & 0 & 0 & 0 & 0 & 0 & 0 & 0 \\
\hline$P$. gonotyl & 1 & 1 & 0 & 0 & 0 & 0 & 0 & 0 & 0 & 0 & 0 \\
\hline$P$. gairhei & 1 & 0 & 1 & 1 & 0 & 0 & 1 & 0 & 0 & 0 & 0 \\
\hline$P$. macroclemidis & 1 & 0 & 0 & 1 & 0 & 0 & 0 & 0 & 0 & 0 & 0 \\
\hline$P$. productum & 1 & 0 & 0 & 0 & 0 & 0 & 1 & 0 & 0 & 0 & 0 \\
\hline$P$. elongatum & 1 & 0 & 2 & 0 & 0 & 0 & 2 & 1 & 0 & 0 & 0 \\
\hline$P$. crocodili & 1 & 0 & 2 & 0 & 0 & 0 & 1 & 1 & 1 & 0 & 0 \\
\hline$P$. atae & 1 & 0 & 2 & 0 & 0 & 0 & 1 & 1 & 0 & 1 & 0 \\
\hline$P$. nicolli & 1 & 0 & 2 & 0 & 0 & 1 & 1 & 1 & 0 & 1 & 1 \\
\hline$P$. dorsale & 1 & 0 & 3 & 0 & 0 & 0 & 1 & 0 & 0 & 0 & 0 \\
\hline
\end{tabular}

1. Gonotyl in the form of a solid muscular pad, diagnostic for the genus.

2. Uterine loops occupying $>45 \%$ TBL (0); uterine loops occupying $<45 \%$ TBL (1).

3. Anal pores opening laterally, at the same level (0); anal pores opening laterally, at different levels (1); anal pores opening at posterior end (2); anal pores opening dorsolaterally (3).

4. Vitelline follicles extending anterior to the posterior margin of the seminal vesicle (0); vitelline follicles not extending anterior to the posterior margin of the seminal vesicle (1).

5. Caeca not atrophied (0); one caecum atrophied (1).

6. Oral spines $<100 \mu \mathrm{m}$ long (0); oral spines $>100 \mu \mathrm{m}$ long (1).

7. Ratio of body length:width $<7.5: 1(0) ; 7.5-15: 1(1) ;>20: 1$ (2).

8. Maximum TBL $<7 \mathrm{~mm}(0) ; 7-16 \mathrm{~mm}(1)$.

9. Forebody $>10 \%$ TBL (0); forebody $<10 \%$ TBL (1).

10. Average ratio of oral sucker width:pharynx width 1:0.4 $(0) ;<1: 0.4$ and $>1: 0.25$ (1).

11. Vitelline follicles not extending anterior to the ventral sucker (0); vitelline follicles extending anterior to the ventral sucker (1). 
Family Cryptogonimidae Ward, 1917

Subfamily Acanthostominae Poche, 1926

Genus Proctocaecum Baugh, 1957

\section{Proctocaecum gairhei n. sp.}

Type-host: Gharial Gavialis gangeticus (Gmelin), Gavialidae.

Type-locality: Gharial Breeding Centre of the Chitwan National Park, Kasara, Chitwan, Nepal.

Site of infection: Small intestine.

Prevalence: $5.84 \%$ (8 of 137 gharial hatchlings).

Type-specimens: Holotype, BMNH 2008.6.16.1; nine paratypes, BMNH 2008.6.16.2-10.

Etymology: The new species is named for Dr Kamal P. Gairhe, Veterinary Officer at the

Chitwan National Park, who kindly made the specimens available.

\section{Description (Fig. 1A-E)}

[The description is based on 10 whole-mounts. Included in the text are the measurements of the holotype. Measurements of the type-series, including the holotype, are presented in Table 2.] Body elongate and slender, with approximately same width throughout or slightly tapering towards posterior end (Fig. 1A). Body length, 4,007; width at level of ventral sucker, 391; ratio of body length to width, 10.2:1. Tegument without spines; latter likely to have been lost in thawing. Retractable oral sucker funnel-shaped, $294 \times 294$, terminal, with strong musculature, surrounded by single, uninterrupted row of 23 spines; spines 36-43 $(40.3 \pm 2.3) \times 14-19(17.0 \pm 1.9)$, rounded at anterior end but pointed at posterior end. Ventral sucker slightly transversally elongate, $171 \times 216$. Forebody (measured from anterior extremity to centre of ventral sucker) $16 \%$ of TBL. Oral to ventral sucker width ratio 1:0.7. Pharynx barrel-shaped, $141 \times 172$, often displaced laterally, obscuring prepharynx. Pharynx almost immediately followed by intestinal bifurcation which is immediately anterior to ventral sucker, merely allowing sufficient space for gonotyl. Ratio of oral sucker width to pharynx width 1:0.6. Caeca not atrophied, open laterally at different levels; right anal pore at 102 from posterior extremity; left anal pore at 159 from posterior extremity. 

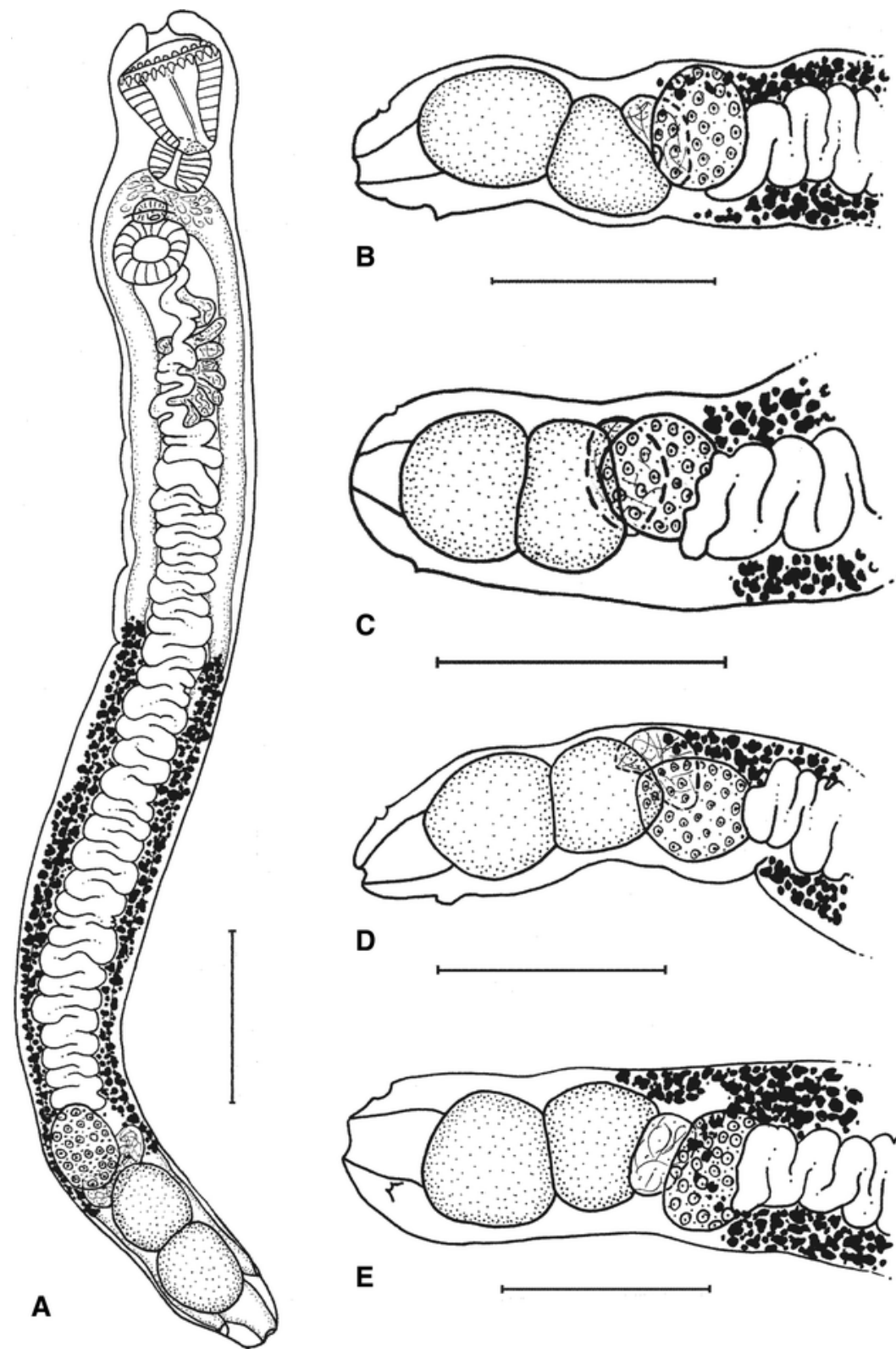

B

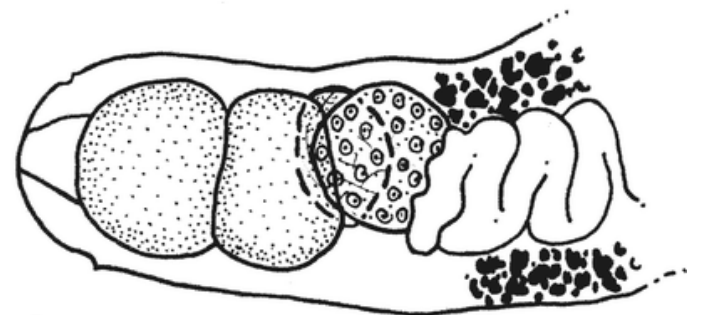

C
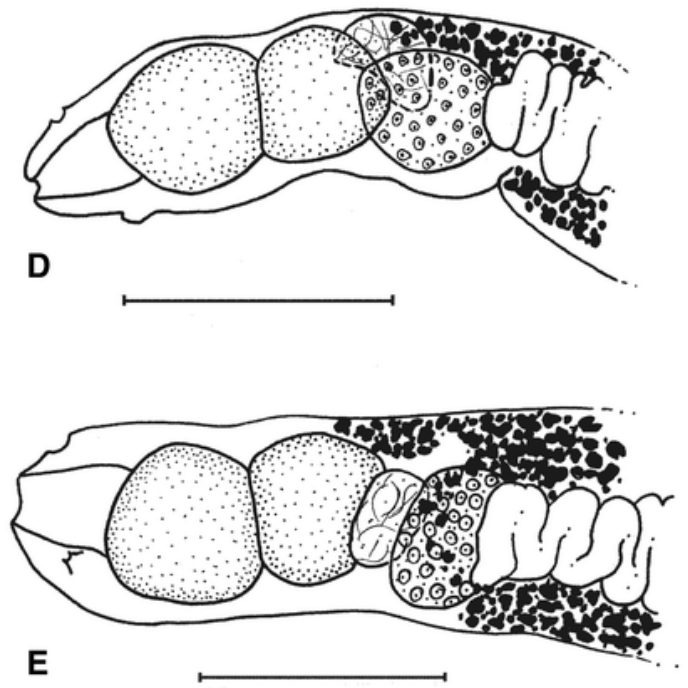

Fig. 1 Proctocaecum gairhei n. sp. from Gavialis gangeticus (Gmelin). (A) Entire holotype; (B-E) Posterior extremity of some of the paratypes illustrating the variation in the arrangement of testes, seminal receptacle, ovary and posterior limit of the vitelline fields. Scale-bars: $500 \mu \mathrm{m}$ 
Table 2 The morphological characteristics of Proctocaecum gairhei n. sp. $(\mathrm{n}=10)$ from Gavialis gangeticus (Gmelin) in Nepal. All measurements are in micrometres

\begin{tabular}{|c|c|c|c|}
\hline Characters & Range & Average & SD \\
\hline Body length & $2,871-4,540$ & 3,749 & 479 \\
\hline Body width at ventral sucker & $335-456$ & 376 & 40 \\
\hline Body length/width & $8-12$ & 10 & 1.1 \\
\hline Oral sucker length & $243-321$ & 291 & 21.6 \\
\hline Oral sucker width & $264-330$ & 300 & 23.4 \\
\hline Ventral sucker length & $160-194$ & 173 & 10.8 \\
\hline Ventral sucker width & $192-245$ & 212 & 17.5 \\
\hline Pharynx length & $127-167$ & 148 & 13.6 \\
\hline Pharynx width & $137-188$ & 163 & 16.3 \\
\hline Gonotyl length & $45-52$ & 47 & 2.7 \\
\hline Gonotyl width & $67-81$ & 72 & 5.3 \\
\hline Forebody & $581-666$ & 627 & 32.3 \\
\hline Ovary length & $144-253$ & 204 & 29.3 \\
\hline Ovary width & $148-195$ & 177 & 16.9 \\
\hline Seminal receptacle length & $85-129$ & 112 & 14.6 \\
\hline Seminal receptacle width & $84-288$ & 186 & 63.3 \\
\hline Anterior testis length & $164-251$ & 217 & 31.7 \\
\hline Anterior testis width & $181-261$ & 214 & 24.3 \\
\hline Posterior testis length & $199-283$ & 250 & 27.4 \\
\hline Posterior testis width & $182-255$ & 224 & 27.4 \\
\hline Ventral sucker to vitelline fields & $349-1,080$ & 637 & 218 \\
\hline Anterior end to vitelline fields & $850-1,825$ & 1,264 & 295 \\
\hline Vitelline fields to posterior end & $537-1,309$ & 722.2 & 235 \\
\hline Right anal pore to posterior end & $52-102$ & 79 & 18.5 \\
\hline Left anal pore to posterior end & $132-171$ & 154 & 15.4 \\
\hline Egg length & $35-38$ & 37 & 1.1 \\
\hline Egg width & $16-17$ & 17 & 0.3 \\
\hline Number of cephalic spines & 23 & 23 & 0.0 \\
\hline Length of cephalic spines & $35-50$ & 43 & 6.8 \\
\hline Width of cephalic spines & $14-21$ & 18 & 2.9 \\
\hline Oral/ventral sucker width & $1: 0.6-0.8$ & $1: 0.7$ & 0.1 \\
\hline Oral sucker/pharynx width & $1: 0.4-0.6$ & 1:0.6 & 0.1 \\
\hline
\end{tabular}




\begin{tabular}{|l|l|l|l|}
\hline Characters & Range & Average & SD \\
\hline Body length/forebody length (\%) & $14-21$ & 17 & 2.6 \\
\hline Percentage of TBL occupied by uterine loops & $59-67$ & 63 & 2.4 \\
\hline
\end{tabular}

Testes contiguous, tandem, at posterior end of body, spherical or subspherical with smooth margins, anterior testis $229 \times 193$, posterior testis $252 \times 191$. Seminal vesicle coiled. Pre-acetabular pit a transverse tegumental slit containing gonotyl in form of solid muscular pad; gonotyl $45 \times 69$. Genital pore median, immediately anterior to ventral sucker.

Ovary pretesticular, round to oval, $226 \times 164$, separated from anterior testis by seminal receptacle, but overlaps anterior testis slightly in contracted specimens. Seminal receptacle posterodorsal to ovary, $97 \times 236$. Region of oötype obscured by eggs. Laurer's canal not seen. Uterine loops occupy $63 \%$ of TBL, situated in intercaecal space between ovary and ventral sucker. Two distinct fields of small vitelline follicles extend on either side of body, remaining either extracaecal or overlapping caeca slightly. In 2 paratypes, posterior border of seminal vesicle coincides with anterior limit of vitelline fields, but in holotype and remaining 7 paratypes anterior border of vitelline fields well posterior to posterior margin of seminal vesicle. Posteriorly vitelline fields extend to anterior border of anterior testis in holotype; in other specimens posterior limit of vitelline fields ranges from level of anterior border of ovary to mid-level of anterior testis (Fig. 1B-E). Fullydeveloped eggs operculate, spindle-shaped, $35 \pm 1.4 \times 17 \pm 0.6$.

Excretory vesicle Y-shaped, with terminal excretory pore; bifurcation not seen, but arms extend to mid-level of ventral sucker.

\section{Discussion}

By having anal openings positioned laterally, Proctocaecum gairhei n. sp. resembles $P$. coronarium, $P$. gonotyl, $P$. vicinum, $P$. productum and $P$. macroclemidis, and differs from $P$. atae, $P$. nicolli, $P$. elongatum and $P$. crocodilii, which have the anal openings at the end of the body (Brooks, 1980), and from $P$. dorsale, in which the anal openings are situated dorsolaterally (Brooks, 2004). In P. coronarium, one caecum is atrophied, setting it apart from the remaining species, and the forebody reaches $25-40 \%$ of the TBL, averaging $31 \%$ (Brooks, 1980), which further separates it from the new taxon. In $P$. gonotyl, the caeca open at this same level and the species is further distinguished from the present specimens by a lower body length to width ratio, namely 6-8:1 as opposed to 811.7:1 in $P$. gairhei. Also, in $P$. gonotyl the vitelline follicles extend anteriorly to the posterior margin of the seminal vesicle. Another species whose caeca open at the same level, is $P$. productum. Other characteristics distinguishing $P$. productum from $P$. gairhei are the smaller oral sucker to pharynx width ratio, 1:0.25-0.28 in $P$. productum (see Brooks, 1980), and the fact that the vitelline field reaches the posterior margin of the seminal vesicle anteriorly and the testicular contiguity posteriorly (Brooks, 1980). While $P$. vicinum shares the same number of cephalic spines (23) as the present specimens and its caeca open at asymmetrical levels, it has a smaller body length to width ratio (5-8:1), 
the forebody makes up 30\% of the TBL, the uterine loops occupy only $40 \%$ of the TBL and its eggs are shorter than those of $P$. gairhei, measuring only $26 \mu \mathrm{m}$ in length (Brooks, 1980). P. macroclemidis possesses a larger number of cephalic spines (26) and, rather than being pointed at their posterior end, as observed in the new taxon, these spines are rounded anteriorly and posteriorly (Tkach \& Snyder, 2003). While the pharynx is distinctly smaller than the ventral sucker in the present specimens (average $148.1 \times 162.7$ and $172.8 \times 211.8 \mu \mathrm{m}$, respectively), these structures are of similar size in $P$.

macroclemidis (average $170 \times 160$ and $150 \times 170 \mu \mathrm{m}$, respectively) (Tkach \& Snyder, 2003).

In addition, $P$. atae differs from $P$. gairhei in the larger number of spines (25-26 in $P$. atae) and a smaller oral sucker to ventral sucker width ratio (1:0.5 in $P$. atae) (Brooks, 1980). The eggs of $P$. nicolli are longer (38-44 $\mu \mathrm{m})$ than those of the present species (35$38 \mu \mathrm{m}$ ), and in P. elongatum the forebody only reaches 7\% of the TBL (Brooks, 1980) as opposed to $14-21 \%$ in the new taxon. $P$. crocodilii is distinguished from the present specimens by the size of the vitelline fields. In the former, the vitelline follicles extend anteriorly to the posterior margin of the seminal vesicle and posteriorly to the middle of the posterior testis (Brooks, 1980), whereas in P. gairhei they do not usually reach the seminal vesicle anteriorly and only in one specimen did the posterior border of the vitelline follicles extend as far back as the anterior half of the anterior testis.

In many ways, $P$. gairhei closely resembles the description of another acanthostomine trematode, Acanthostomum slusarskii Kalyankar, 1977, collected from Crocodylus palustris (Lesson) in India, and the present authors initially considered the present specimens to belong to the latter species. Because of the presence of a gonotyl in the current material, this would have meant transferring A. slusarskii to Proctocaecum. Incidentally, Lamothe-Argumedo \& Ponciano-Rodríguez (1985) made this transfer, but, since it was done without examining specimens, without a phylogenetic analysis, without any discussion of the phylogenetically-based classification proposed by Brooks (1980) and revised by Brooks \& Holcman (1993), and because the transfer was solely based on the fact that $A$. slusarskii was reported from a crocodilian, we do not accept their view. We instead use the classification in Brooks \& McLennan (1993) based on specimens and a phylogenetic analysis.

The main similarities between the new taxon and A. slusarskii are the ratio of oral to ventral sucker width (1:0.6-0.8 in both species), oral sucker to pharynx width (1:0.4-0.6 vs 1:0.6-0.7 in A. slusarskii) and a forebody reaching 14-21\% of TBL in the present specimens and $20 \%$ in A. slusarskii (see Brooks, 1980). The extent and position of the vitelline fields are very similar in the two species, in that they do not reach the posterior margin of the seminal vesicle in A. slusarskii (see Kalyankar, 1977; Brooks, 1980) and, with the exception of two of ten specimens, end well posterior to the seminal vesicle in $P$. gairhei. In both species the vitelline follicles extend posteriorly to the ovary, ending immediately postovarian in A. slusarskii (see Kalyankar, 1977; Brooks, 1980) but sometimes reaching the mid-level of the ovary or the anterior border of the anterior testis or even its mid-level in the new species. These slight variations seem to reflect the stage of body contraction. Further similarities are the percentage of the TBL occupied by 
uterine loops, namely 59-67\% in the new taxon and 70\% in A. slusarskii, and caeca that open laterally (Brooks, 1980). As in A. slusarskii (see Kalyankar, 1977), body spines were not seen in our specimens; however, the hosts had been frozen and thawed before the material was collected and fixed in $70 \%$ ethanol and spines might have been lost during the process.

The main difference between the present specimens and those described by Kalyankar (1977) is the presence of the solid, muscular gonotyl diagnostic for Proctocaecum in the former and the apparent lack of such a structure in A. slusarskii, which formed the basis of its allocation to Acanthostomum (Brooks, 1980). In the original description of $A$. slusarskii, Kalyankar (1977) mentioned neither pre- nor post-acetabular slits, and his only reference to morphological structures in the vicinity of the ventral sucker was that the genital atrium "is median and immediately pre-acetabular". However, the absence or presence of a gonotyl cannot be confirmed, because the type-specimens either do not exist or are not available for study (Brooks, 1980).

Moreover, the number of cephalic spines is larger in $P$. gairhei than in A. slusarskii (23 vs 18-19) and the caeca in our specimens do not open at the same level, as they do in $A$. slusarskii (see Brooks, 1980), but at different distances from the posterior extremity (Fig. 1B-E). The testes (164-283 × 181-261 vs 300-420 × 300-420 $\mu \mathrm{m})$, oral sucker $(243-321 \times 264-330 v s 400 \times 420$ and $400 \times 450 \mu \mathrm{m})$ and ventral sucker $(160$ $190 \times 192-245$ vs 260-370 $\mu \mathrm{m}$ in diameter) are smaller in the present specimens than in A. slusarskii (see Kalyankar, 1977). Egg size is generally considered a robust taxonomic trait, and those of $P$. gairhei are larger than those of A. slusarskii (35-38 $\times 16-17$ vs 30$34 \times 10-13 \mu \mathrm{m})$.

In short, despite some obvious similarities, there are morphological features which clearly distinguish the two species. Hence, the present specimens cannot be A. slusarskii, and there is thus no reason to transfer A. slusarskii to Proctocaecum.

Adding $P$. gairhei to the existing phylogenetic database for Proctocaecum produces the cladogram shown in Fig. 2. The new species occurs in a polytomy comprising the African $P$. productum, the South American $P$. dorsale and the Indo-Pacific $P$. atae $+P$. elongatum $+P$. crocodili clade. This reinforces the evolutionary interpretation proposed by Brooks (2004) that, originating in Africa, Proctocaecum spread to North America, South America and the Indo-Pacific before the breakup of Pangea. Hence, the North American and South American species are more closely related to African species than they are to each other. Brooks (2004) concluded that the common ancestor of the group originated in crocodylids and that the host spectrum was expanded as a result of hostswitching. 


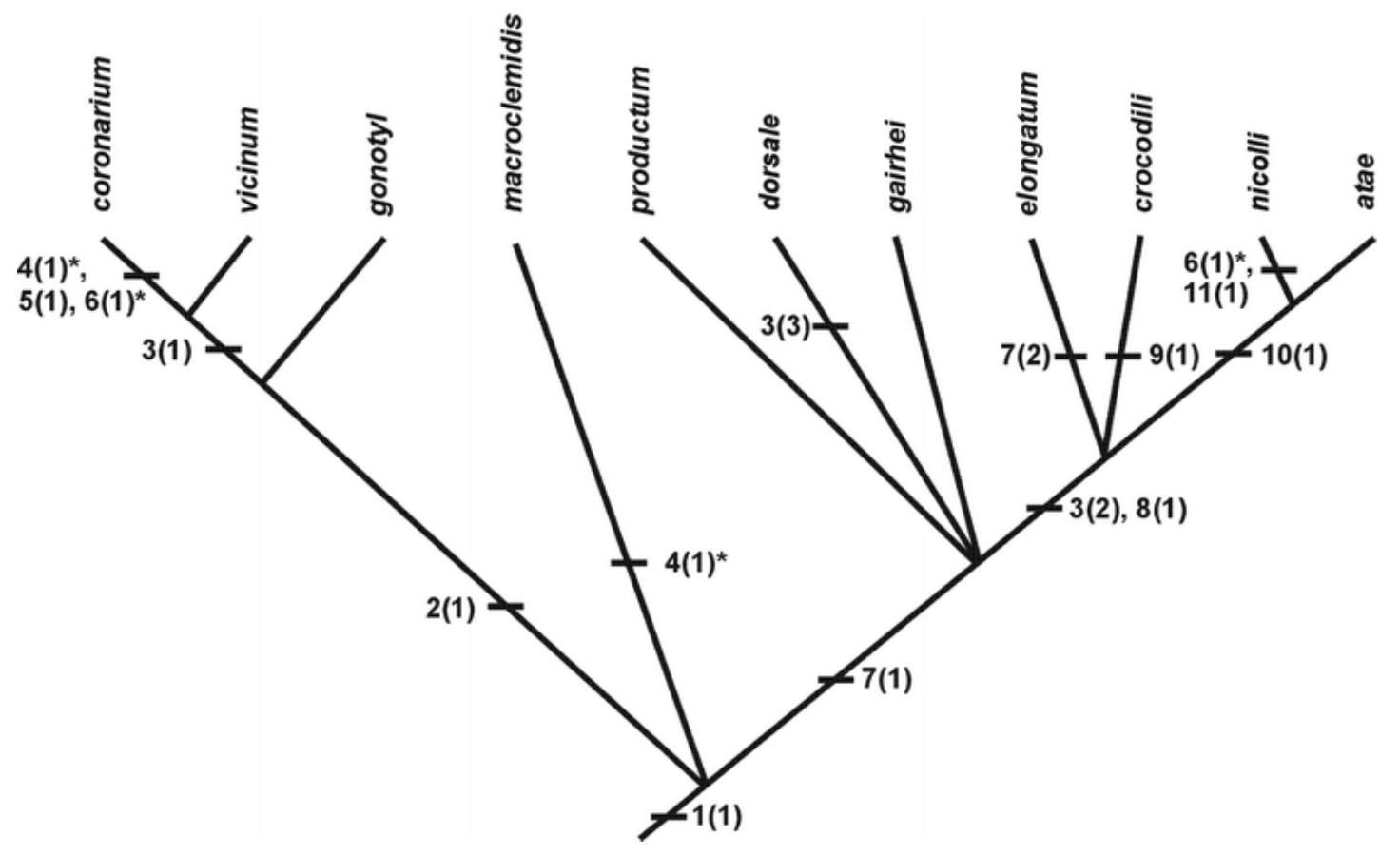

Fig. 2 Phylogenetic hypothesis for Proctocaecum spp. Numbers accompanying slash marks on branches refer to the synapomorphic traits specified in the 'Materials and methods'; an asterisk indicates homoplasy. For a discussion of the traits and polarity decisions, see Brooks (2004)

P. gairhei could not be associated directly with the death of gharial hatchlings, but an "enlargement and shortening of the duodenum and the gross thickening of the mucosa at the opening of the bile duct into the duodenum" observed in two hatchlings were attributed to its presence (Gairhe, 2007). To the contrary, another acanthostomine parasite, Timoniella loossi (Pérez Vigueras, 1957), has been inferred to be involved with the poor development, decreased vitality and weight loss of hatchlings of Crocodylus acutus and $C$. rhombifer Cuvier at a commercial hatchery in Cuba (Pérez Benitez, Sardinas \& Benitez, 1980).

While to date only few data have been published on the life-cycles of acanthostomine trematodes, metacercariae belonging to different genera and species of this subfamily have been reported from numerous fish species (Scholz, Vargas-Vásquez, Moravec, Vivas-Rodríguez \& Mendoza-Franco, 1995; Roopa \& Janardanan, 1998; Moravec, 2001). Thus, the most likely route of infection for the gharial hatchlings at the Gharial Breeding Centre is the practice of feeding them fresh fish from a nearby river, which are likely to harbour natural infections. Gairhe (2007) therefore suggested following Foggin (1992) and to freeze fish for at least 72 hours before feeding in order to kill parasite larvae. 


\section{References}

Brooks, D. R. (1980). Revision of the Acanthostominae Poche, 1926 (Digenea:

Cryptogonimidae). Zoological Journal of the Linnean Society, 70, 313-382.

Brooks, D. R. (2004). Comments on the gonotyl of Proctocaecum macroclemidis (Tkach and Snyder, 2003) n. comb. (Digenea: Acanthostomidae: Acanthostominae), with a key to the genera of Acanthostominae and a new phylogenetic tree for Proctocaecum Baugh, 1957. Journal of Parasitology, 90, 594-597.

Brooks, D. R., \& Holcman, B. (1993). Revised classification and phylogenetic hypothesis for the Acanthostominae Looss, 1899 (Digenea: Opisthorchiformes: Cryptogonimidae). Proceedings of the Biological Society of Washington, 106, 207-220.

Brooks, D. R., \& McLennan, D. A. (1993). Parascript, parasites and the language of evolution (429 pp). Washington, DC: Smithsonian Institution Press.

Catto, J. B., \& Amato, J. F. R. (1993). Digenetic trematodes (Cryptogonimidae, Acanthostominae) parasites of the Caiman, Caiman yacare (Reptilia, Crocodylia) from the Pantanal Mato-Gossense, Brazil, with the description of a new species. Memórias do Instituto Oswaldo Cruz, 88, 435-440.

Foggin, C. M. (1992). Diseases of farmed crocodiles. In G. A. Smith \& J. Marias (Eds.), Conservation and utilization of the Nile crocodile in Southern Africa. Handbook on crocodile farming (pp. 107-140). Pretoria: The Crocodile Study Group of Southern Africa.

Gairhe, K. P. (2007). An investigation on the causes of mortality in captive gharial hatchlings at the Chitwan National Park, Nepal. Dissertation, Tribhuvan University.

Kalyankar, S. D. (1977). Acanthostomum slusarskii sp. n. (Trematoda, Acanthostomidae) from Crocodilus palustris Less in India. Acta Parasitologica Polonica, 24, 227-230.

Lamothe-Argumedo, R., \& Ponciano-Rodríguez, G. (1985). Revision de la subfamilia Acanthostominae Nicoll, 1914 y establecimiento de dos nuevos generos. Anales del Instituto de Biología, Serie Zoología, Universidad Nacional Autónoma de México, 56, 301-322.

Moravec, F. (2001). Some helminth parasites from Morelet's crocodile, Crocodylus moreletii, from Yucatan, Mexico. Folia Parasitologica, 48, 47-62. 
Pérez Benitez, I., Sardinas, G., \& Benitez, A. (1980). Hallazgo y evolución de una parasitosis aguda producida por Acanthostomum loossi Pérez Vigueras, 1956 en animales jóvenes de una cría industrial de crocodilos (Crocodylus acutus Cuvier y Crocodylus rhombifer Cuvier). Revista Cubana de Ciencias Veterinarias, 11, 79-83.

Roopa, T. M., \& Janardanan, K. P. (1998). The life cycle of Acanthostomum burminis (Trematoda, Acanthostomidae). Acta Parasitologica, 43, 189-193.

Scholz, T., Vargas-Vásquez, J., Moravec, F., Vivas-Rodríguez, C., \& Mendoza-Franco, E. (1995). Metacercariae of trematodes of fishes from cenotes (= sinkholes) of the Yucatan Peninsula, Mexico. Folia Parasitologica, 42, 173-192.

Tkach, V. V., \& Snyder, S. D. (2003). Acanthostomum macroclemidis n. sp. (Digenea: Cryptogonomidae: Acanthostominae) from the Alligator snapping turtle, Macroclemys temmincki. Journal of Parasitology, 89, 159-167. 